\section{Cosmetic neurology}

In a paper that received widely divergent reviews, Anjan Chatterjee surveys how novel treatments for motor, cognitive, and emotional disorders might enhance these systems in healthy individuals. Introducing such quality of life treatment of normal subjects raises ethical concerns. However, Chatterjee anticipates that there are unlikely to be major restraints on cosmetic neurology.

see page 968

Stephen Hauser's editorial, "The shape of things to come," considers further implications of Chatterjee's arguments and focuses on six emerging medical technologies-cosmetic pharmacology, human cloning, stem cell research, preimplantation genetic selection, genetic engineering, and artificial interfaces and nanotechnology - to argue for a unique role for neurologists as principal physicians of the human nervous system. He suggests that we should assume a central role in shaping the debate about the boundary between interventions used to promote or restore optimal health and those used for enhancement. He further suggests changes and additions to neurology training to prepare the next generation of neurologists for this expanded role.

see page 948

"If we accept slipperyslope arguments like Chatterjee's, we are left thinking that we have no recourse when the forces of the market and the power of the military combine to foist a change upon us... [but] ...there is nothing inevitable about the course of our society or of neurology as a profession.”

The editorial by Richard H. Dees rejects the inevitability of Chatterjee's claims. Chatterjee, he contends, falls prey to the "allure of the slippery slope" to induce us to accept an argument we should simply reject. In so doing, Dees argues, Chatterjee simply evades the very real moral questions about what kind of doctors neurologists should be and what kind of society we should become.

see page 951

\section{Plasma exchange for severe optic neuritis}

Reviewing a case series of 10 patients treated with plasma exchange for steroid-unresponsive optic neuritis, Ruprecht et al. found that this treatment may be beneficial in some of these patients.

\section{Depression in community-based patients with epilepsy or asthma}

Using a mail survey integrating validated self-report measures in community-based patients ( $\mathrm{n}=1,522)$, Ettinger et al. found significant depression scores in epilepsy (36.5\%) and asthma patients (27.8\%) vs healthy controls (11.8\%). Depression was often under-recognized and correlated with diverse psychosocial impairments.

see page 1008

\section{Intracerebral hemorrhage expansion in warfarin patients}

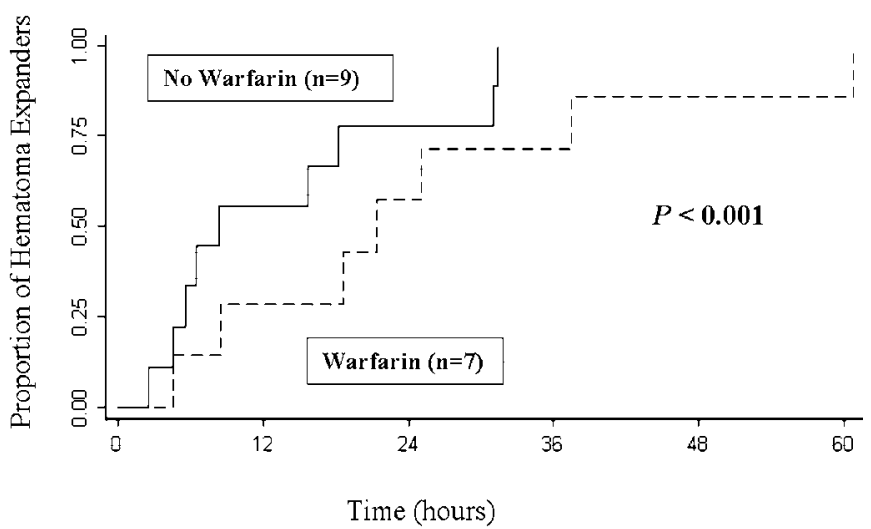

ICH patients are twice as likely to die if they are taking warfarin at the time of hemorrhage. Flibotte et al. found that warfarin patients were at increased risk of continued bleeding and hemorrhage expansion during hospital admission. This bleeding appeared to contribute to warfarin's effect on ICH mortality.

see page 1059

\section{Clinical and laboratory assessment of distal peripheral nerves in Gulf War veterans and spouses}

Davis et al. conducted standardized neurologic and nerve conduction examinations in 1,061 deployed and 1,128 non-deployed 1990-1991 Persian Gulf veterans and their spouses. Deployed and non-deployed veterans demonstrated similar prevalences of distal symmetrical polyneuropathy. No prevalence differences were found between spouse groups. 


\section{Association studies of the $A B C B 1$ gene in epilepsy pharmacoresistance}

\section{Not guilty by association}

The $A B C B 1$ gene was previously implicated in epilepsy pharmacoresistance by association analysis. Here, Tan et al. could not confirm this, even with doubling of the sample size.

\section{Guilty by association}

see page 1090

Zimprich et al. reexamined the role of variations in the $A B C B 1$ gene, which looks for the multidrug transporter P-glycoprotein. They genotyped 210 patients with temporal lobe epilepsy who were stratified according to their degree of drug resistance. They identified a common haplotype that when present in the homozygous state significantly increased the risk for pharmacoresistance.

see page 1087

\section{Replication of association studies}

Neurology's Information for Authors currently reflects a 2001 editorial. It was modified after a 2004 article noting flaws in some of Neurology's association studies. Now, in commenting on the original New England Journal of Medicine paper and this issue's contradictory papers, statistical geneticist Jurg Ott raises the bar for Neurology association studies by reviewing reasons for non-replication and then outlining the hurdles a good association study should overcome.

see page 955

\section{Treatment of headache associated with dipyridamole/aspirin}

Lipton et al. treated elderly patients with a dipyridamole/aspirin combination (DAC) vs placebo and found that most (61\%) did not develop headaches. When headaches developed they usually remitted within 2 hours with either acetaminophen or placebo treatment. Even in patients who get headaches, most remitted over a 7-day course. Patients with DAC associated headaches can be reassured that their headaches will usually improve.

see page 1099

\section{Natural history of conservatively treated meningiomas}

Herscovici et al. evaluated the clinical outcome and growth rate of 51 conservatively treated meningiomas (mean follow-up 67 months). Growth did not occur in 32 tumors in 28 patients (63\%). Growth occurred in 19 tumors in 16 patients (37\%). Mean growth was 4 $\mathrm{mm} /$ year.

see page 1133

\section{VIDEO ALERT}

This issue of Neurology has two videos posted online:

- Glabellar and palmomental reflexes in parkinsonian disorders H. Brodsky, K. Dat Vuong, M. Thomas, and J. Jankovic Neurology 2004;63:1096-1098

- Intracranial EEG study of seizure-associated nose wiping H. Catenoix, M. Guénot, J. Isnard, C. Fischer, F. Mauguière, and P. Ryvlin Neurology 2004:63:1127-1129

Access www.neurology.org and search for the articles. Click on Video to view. 


\section{Neurology}

September 28 Highlights

Neurology 2004;63;946-947

DOI 10.1212/01.WNL.0000142212.48350.0C

This information is current as of September 27, 2004

\section{Updated Information \&} Services

Permissions \& Licensing

\section{Reprints}

including high resolution figures, can be found at: http://n.neurology.org/content/63/6/946.full

Information about reproducing this article in parts (figures,tables) or in its entirety can be found online at:

http://www.neurology.org/about/about_the_journal\#permissions

Information about ordering reprints can be found online:

http://n.neurology.org/subscribers/advertise

Neurology ${ }^{\circledR}$ is the official journal of the American Academy of Neurology. Published continuously since 1951, it is now a weekly with 48 issues per year. Copyright . All rights reserved. Print ISSN: 0028-3878. Online ISSN: 1526-632X.

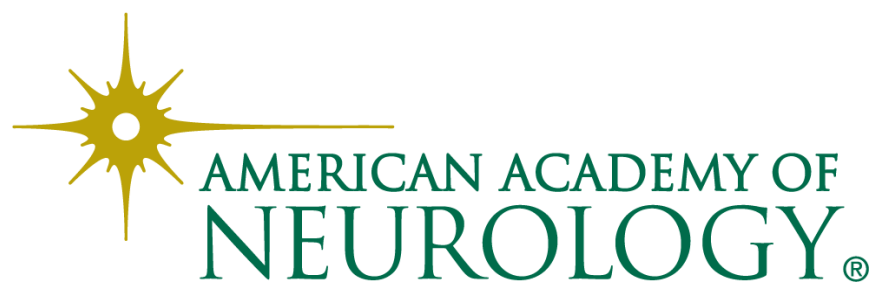

